coronary artery in each case, and marked cardiac enlargement in seven out of eight men with persistent bundle-branch block who died within two months of their first infarction. When advanced surgical techniques become available to patients with acute myocardial infarction it is unlikely that any procedure short of replacement of the heart will benefit patients with bundle-branch block because of the extensive infarction usually involving the septum, severe coronary artery disease, and evidence of cardiac hypertrophy.

We wish to thank the physicians of the Royal Melbourne Hospital for permission to study cases under their care.

\section{REFERENCES}

Bauer, G. E., Julian, D. G., and Valentine, P. A. (1965). Brit. Heart J. 27,724 .

Denborough, M. A., Lovell, R. R. H., Nestel, P. J., and Goble, A. J. (1968). Lancet, 1, 386.

Epstein, E. J., Coulshed, N., McKendrick, C. S., Clarke, J., and Kearns, W. E. (1966). Brit. Heart ₹., 28, 546

Godman, M. J., Lassers, B. W., and Julian, D. G. (1968). In preparation. Hipp, H. R., Beard, O. W., Taylor, J. S., Ebert, R. V., and Robins, M. (1961).' Amer. Heart f̈., 62, 43 . Imperial, E. S., Carballo R., and Zimmerman, H. A. (1960). Amer. Y.

Lassers, B. W., and Julian, D. G. (1968). Brit. med. 7., 2, 142

Mintz, S. S., and Katz, L. N. (1947). Arch. intern. Med., 80, 205.

Robinson, J. S., Sloman, G., and McRae, C. (1964). Med. F. Aust., 1, 427. Rose, G. A., and Blackburn, H. (1968). Wld Hlth Org. Monogr. Ser.,
No. 56.

\title{
Plasminogen-activator-producing Tumour
}

\author{
J. F. DAVIDSON,* M.B., M.R.C.P.BD. ; G. P. MCNICOL, $\dagger$ M.D., PH.D., F.R.C.P.ED., F.R.C.P.GLASG. \\ G. L. FRANK, $\ddagger$ M.B., M.C.PATH.; T. J. ANDERSON,§ M.B., СH.B. \\ A. S. DOUGLAS, $\|$ M.D., F.R.C.P., F.R.C.P.ED., F.R.C.P.GLASG.
}

Brit. med. F., 1969, 1, 88-91

\begin{abstract}
Summary : In a patient with giant-cell carcinoma of the lung a secondary tumour deposit in the arm was incised and bled for three weeks. Investigations showed the tumour to be rich in plasminogen activator. Haemostasis in the tumour was achieved with aminocaproic acid therapy. For a period the plasminogen-activator properties were retained in cell culture of the tumour.
\end{abstract}

\section{Introduction}

Malignant disease, particularly disseminated carcinoma, may be complicated by a haemostatic defect which can arise during the course of the disease or during surgery. This can take the form of disseminated intravascular coagulation or pathological fibrinolysis. Elucidation of the pathogenesis is important in view of the different mechanisms which require different therapeutic measures. Straub, Riedler, and Frick (1967) reported disseminated intravascular coagulation with hypofibrinogenaemia and secondary fibrinolysis in a case of generalized prostatic carcinoma which responded to heparin therapy. Tagnon, Schulman, Whitmore, and Leone (1953) found pathological fibrinolysis in a prostatic carcinoma and evidence of proteolytic activity in a bone metastasis. Hormonal therapy directed against the tumour produced remission both of the tumour and of the fibrinolytic state.

According to current concepts (McKay, 1965 ; Straub et al., 1967) the defibrination syndrome found in malignant disease is usually caused by disseminated intravascular coagulation. Certain cases remain, however, in which this is not a satisfactory explanation, and where investigation indicates primary pathological fibrinolysis as the pathogenetic mechanism.

In this report the findings are recorded in a patient with a secondary carcinoma of the arm which when incised developed

\footnotetext{
* Senior Registrar in Haematology, Glasgow Royal Infirmary. + Senior Lecturer in Medicine, Glasgow Royal Infirmary. ‡Consultant in Laboratory Medicine, Glasgow Royal Infirmary. Registrar in Laboratory Medicine, Glasgow Royal Infirmary. Present address, Department of Biochemistry, Glasgow University. 11 Professor of Medicine, Glasgow Royal Infirmary.
}

a localized haemostatic defect without systemic abnormality. So far as we are aware this is the first reported case of a plasminogen-activator-producing tumour with localized defective tumour haemostasis.

\section{Case Report}

A 71-year-old housewife presented at the casualty department in May 1967 with a three-weeks history of pain in the left forearm and difficulty in extending the fingers. Her previous health had been good, and there was no systemic upset.

On examination a warm indurated swelling of the flexor aspect of the left forearm with some surrounding induration was found. One small lymph node was palpable in the left axilla. There was stiffness of the fingers. Physical examination was otherwise unremarkable.

A diagnosis of cellulitis of the forearm was made and penicillin given. After seven days there was no improvement, so the swelling was incised and explored. Only sterile serosanguineous material was obtained, and no pus was found. Ten days later, when the swelling and tenderness were extending proximally, a second incision was made, and again only sterile serosanguineous material was obtained.

The first wound bled steadily for 10 days and the second for 27 days until aminocaproic acid was given (see below). The severity of the blood loss from the arm was indicated by a fall in haemoglobin level from 13.6 to $7.6 \mathrm{~g} . / 100 \mathrm{ml}$. in 14 days. Thereafter only by the transfusion of six bottles of blood over a period of 10 days was a further fall prevented. There was no bleeding from any other site to account for the falling haemoglobin.

When bleeding from the second incision had continued steadily for 10 days it became obvious that there was a defect in haemostasis at the site of the arm swelling, and coagulation and fibrinolytic investigations were undertaken. These are described in detail below.

Despite supportive measures and blood transfusion the patient's general condition deteriorated gradually. Wound fluid was readily obtained by aspiration from the incision, and cytological and histological examination showed it to contain many undifferentiated and poorly differentiated malignant cells. Despite an exhaustive search no primary tumour site was found in life. Radiological studies of the forearm, including angiography, showed no evidence of tumour circulation or bone involvement. 
Though no coagulation and only minor fibrinolytic abnormalities were found in the systemic circulation, studies of the wound fluid showed it to be rich in plasminogen activator (see below). Oral aminocaproic acid was given to inhibit plasminogen activation and thereafter blood loss from the wound virtually ceased. Aminocaproic acid therapy was continued and there was no further significant haemostatic problem (Fig. 1).

Twenty-one days after the second incision the patient collapsed suddenly. There were signs of phlebothrombosis in the right calf and physical signs on chest examination which suggested a clinical diagnosis of pulmonary embolism. Because of the haemostatic problem in the arm anticoagulant therapy was not given. The patient made a moderate recovery, but 10 days later suddenly became febrile, developed signs of bronchopneumonia, and died the next day.

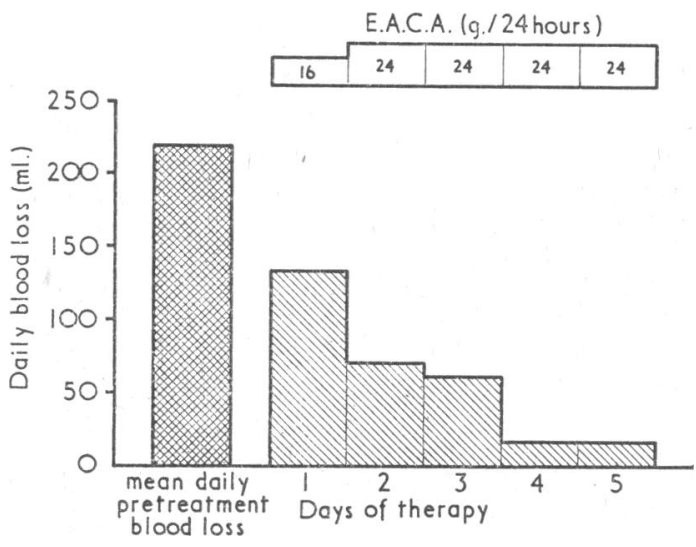

FIG. 1.-Effect of aminocaproic acid (E.A.C.A.) on blood loss from wound.

\section{Materials and Methods}

Blood was taken by clean venepuncture into plastic syringes and transferred to plastic tubes. Nine parts of whole blood were added to one part of $3.8 \%$ sodium citrate. Wound fluid was obtained by gentle aspiration with a plastic syringe. Nine parts of wound fluid were added to one part of $3.8 \%$ sodium citrate. Cell-free plasma and wound fluid were obtained by centrifuging the citrate dilution at $2,800 \mathrm{~g}$ for 10 minutes at $4^{\circ} \mathrm{C}$. A tumour cell suspension was prepared from the wound fluid buffy coat and washed four times in normal saline. Wound fluid buffy coat was also used for histological examination.

Within an hour of death part of the arm tumour was excised and portions were (1) fixed in formalin for histology, (2) snap frozen and kept for plasminogen activator assay, and (3) taken into Medium 199 for tissue culture.

Thrombin time was estimated as described by $\mathrm{McNicol}$ and Douglas (1964), one-stage prothrombin time as described by Douglas (1962), kaolin cephalin clotting-time as described by Denson (1966), factor XIII activity by the method of Soulier, Prou-Wartelle, and Josso (1964), euglobulin lysis time as described by McNicol, Barakat, and Douglas (1965), and fibrinogen assay by the method of Ratnoff and Menzie (1964). Immunoreactive fibrin was assayed by the method of Merskey, Kleiner, and Johnson (1966), plasminogen assay by the method of McNicol and Douglas (1964), urokinase sensitivity test as described by McNicol et al. (1965), and fibrin plate as described by McNicol et al. (1965). Direct smears of wound fluid were prepared, fixed in methanol, and stained by the May-Grünwald-Giemsa method. Wound fluid thromboplastin activity was assessed by the fluid's ability to shorten the recalcification time of normal plasma as shown in Table I.

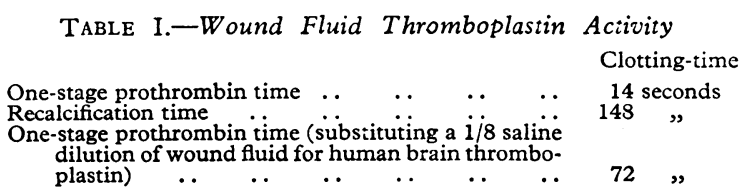

Plasminogen activator activity was assayed on fibrin plates by comparison with a standard urokinase dilution curve. Plasminogen activator activity was also assayed in a caseinolytic system as shown in Fig. 2. The test material after 10 minutes' incubation with plasminogen at $37^{\circ} \mathrm{C}$. was added to casein and incubated again at $37^{\circ} \mathrm{C}$. for 60 minutes. The amount of plasmin evolved was quantitated from the tyrosine released. Tissue plasminogen activator was assayed by the potassium thyocyanate extraction method of Albrechtsen (1957) and quantitated against a standard urokinase dilution curve.

Blood loss from the arm was measured by a modification of the ${ }^{51} \mathrm{Cr}$ red cell method described by Dacie and Lewis (1963).

Portions of tumour tissue were transported on ice in Medium 199 and processed within two hours. A single cell suspension was produced from the tumour tissue by a modification of the method of Moscona (1961). Washed cells were inoculated into aliquots of Eagle's basal medium plus $20 \%$ foetal bovine serum in 2-oz. (57ml.) bottles, which were gassed with $5 \%$ carbon dioxide in air and incubated at $37^{\circ} \mathrm{C}$. Primary cultures of epithelial-like cells were established in 10 days and were harvested by brief exposure to trypsin solution and cloned on $x$-irradiated feeder layers (Puck and Marcus, 1955). Cells derived from these clones were conditioned to growth in Eagle's basal medium with $10 \%$ calf serum and maintained in monolayer culture in Roux flasks by feeding with fresh medium at intervals of three to four days for subculture by trypsinization at confluency.

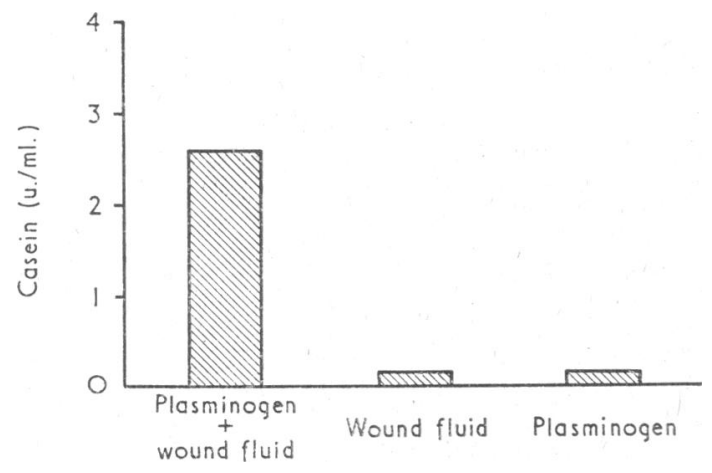

FIG. 2.-Plasminogen activator activity of wound fluidcasein digestion.

Coverslip cultures were prepared by inoculating $10^{\circ}$ cells on to coverslips in $5 \mathrm{ml}$. of medium in 2 -in. $(5-\mathrm{cm}$.) plastic Petri dishes, and incubated at $37^{\circ} \mathrm{C}$. for 36 hours in humidified $5 \%$ carbon dioxide in air. Cells to be tested for plasminogen activator activity were harvested from bottles by scraping with a rubber policeman or by exposure to edetic acid solution (Paul, 1959) and collected into phosphate-buffered saline.

\section{Results}

After the first surgical incision the haemoglobin was 13.6 g./ $100 \mathrm{ml}$, but after the second incision it fell to $7.6 \mathrm{~g} . / 100 \mathrm{ml}$. over a period of 14 days. At no time was there any significant thrombocytopenia, and the peripheral blood film was in keeping with a response to haemorrhage. The haemoglobin level was thereafter maintained at $10 \mathrm{~g} . / 100 \mathrm{ml}$. by blood transfusion.

The mean daily blood loss from the arm in the two days before aminocaproic acid therapy was $216 \mathrm{ml}$. With $16 \mathrm{~g}$. of oral aminocaproic acid a day the blood loss fell to $135 \mathrm{ml}$./day, and when the dose was increased to $24 \mathrm{~g}$./day the blood loss fell to $18 \mathrm{ml}$./day (Fig. 1).

Smears of the serosanguineous wound fluid contained clumps of anaplastic tumour cells. A buffy coat prepared from the wound fluid contained many tumour cells.

Detailed investigations of the systemic haemostatic mechanism were normal (Table II). The only abnormalities found on investigation of the patient's plasma fibrinolytic mechanism were a prolonged euglobulin lysis time and a slightly prolonged urokinase sensitivity test (Table II).

The wound fluid had thromboplastic activity as shown by its ability to shorten the recalcification time of normal plasma (Table I). 
One-stage assays of factor VIII and factor IX in the fluid gave activities of more than $100 \%$ of normal, again suggesting thromboplastic activity.

Table II.-Plasma Coagulation and Fibrinolysis Studies

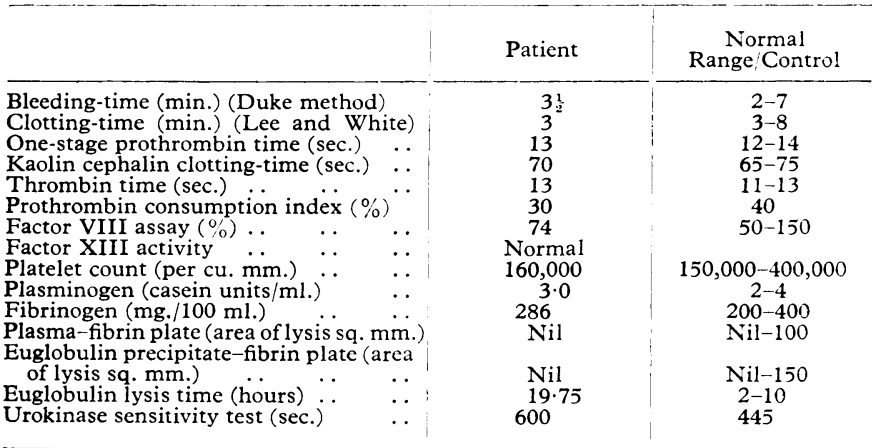

Small amounts of clottable protein and $24 \mathrm{mg}$. of immunoreactive fibrin per $100 \mathrm{ml}$. but no plasminogen or plasmin were detected in the fluid (Table III). The fluid was found to be particularly rich in plasminogen activator (300 Ploug units/ml.). This property was demonstrated by a fibrin plate assay and also by a caseinolytic assay (Table III and Fig. 2). With the use of saline dilutions of the wound fluid on a fibrin plate plasminogen activator was detected up to a dilution of $1 / 800$. The pattern of fibrin digestion in these experiments suggested the presence of plasmin inhibitor, for the area immediately under the drop applied was left unlysed in the centre of a circle of lysis.

TABLE III.-Wound Fluid-Fibrinolytic Studies

\begin{tabular}{|c|c|c|c|c|}
\hline vator & & & & \\
\hline Washed cell suspension - fibrin plate & ysis & oug & its $/ r$ & \\
\hline Proteolysis - heated fibrin plate lysis & .. & .. & .. & \\
\hline Fibrinogen (mg./100 ml.) & .. & . & .. & \\
\hline Immunoreactive fibrin (mg./100 ml.) & .. & . & $\ldots$ & \\
\hline Plasminogen (casein units $/ \mathrm{ml}$.) & $\ldots$ & $\because$ & 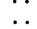 & \\
\hline (cas & $\because$ & $\cdots$ & & \\
\hline
\end{tabular}

A washed suspension of buffy coat tumour cells had plasminogen activator activity. When tested on a fibrin plate the washed buffy coat cells were found to have 48 Ploug units $/ \mathrm{ml}$. plasminogen activator activity (Table III). Some months after death portions of tumour were thawed and homogenized and found to contain 128 Ploug units of plasminogen activator activity per gramme wet weight of tissue.

Portions of tumour were set up in tissue culture. Cells harvested from early-stage monolayer culture of the cloned cells resuspended at a concentration of 8 by $10^{\circ} / \mathrm{ml}$. produced areas of lysis when tested on fibrin plates Table IV, indicating significant plasminogen activator activity. As with the wound fluid, a central area of undigested fibrin remained in each area of lysis, suggesting the presence of inhibitor of plasmin.

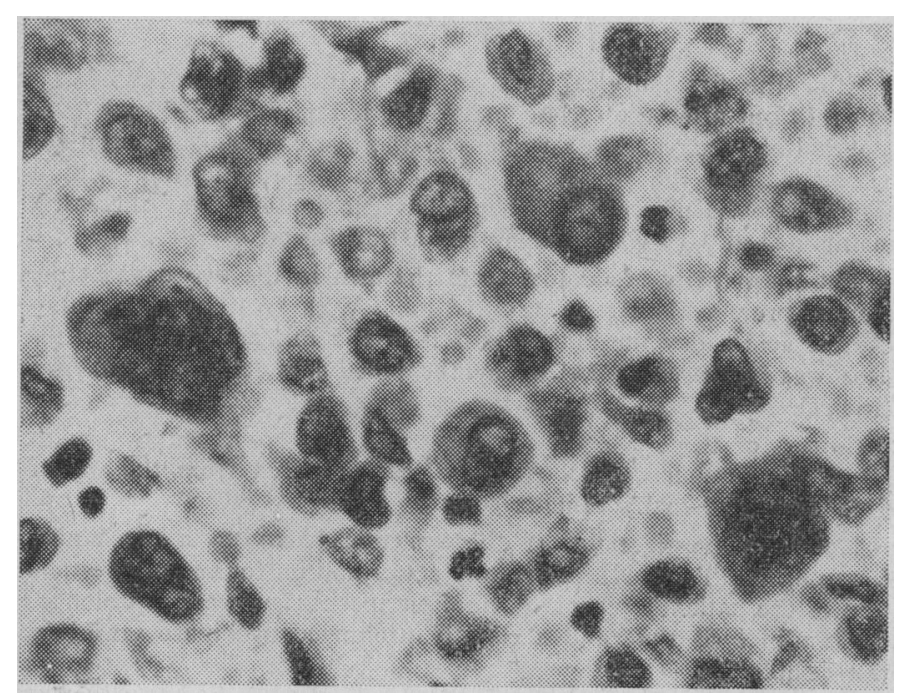

FIG. 3.-Arm tumour section showing adenocarcinoma and giant cells. (Haematoxylin and eosin. $\times 745$.)
TABle IV.-Tumour Tissue Culture-Plasminogen Activator Activity October $\left\{\begin{array}{lll}8 \times 10^{6} \text { cells } / \mathrm{ml} .: & \text { Fibrin plate area of lysis (sq. mm.) } & 162 \\ 6 \times 10^{6} \text { cells } / \mathrm{ml} .: & \text { Fibrin plate area of lysis (sq } \mathrm{mm} \text {.) } & 108\end{array}\right.$ $1967\left\{\begin{array}{l}6 \times 10^{6} \mathrm{cell} / \mathrm{ml} \text {.: Fibrin plate area of lysis (sq. mm.) } \ldots . \\ 8 \times 10^{6} \text { cells } / \mathrm{ml} \text {.: Heated fibrin plate area of lysis (sq. mm.) }\end{array}\right.$ $\begin{array}{ccccc}\text { December 1967: Repeat experiment as above from late stage cultures: } \\ \text { Fibrin plate area of lysis (sq. mm.) } & \ldots & \ldots & \ldots & \ldots\end{array}$ 0

\section{Pathology}

Arm Tumour Biopsy.-Microscopical examination of the piece of tissue showed tumour tissue with fairly extensive necrosis and haemorrhage, composed of sheets of plump round or polygonal cells, $15-40 \mu$ in diameter, among which giant cells $50-100 \mu$ in diameter were prominent. A few giant cells showed phagocytic activity and contained ingested polymorph leucocytes, haemosiderin, or small tumour cells. Nuclei were moderately hyperchromatic, with coarse chromatin clumping, and of ten showed prominent nucleoli (Fig. 3). Because of a resemblance to rhabdomyosarcoma, attempts were made to demonstrate the typical cross-striations of this tumour, but these were negative.

Necropsy.-A friable haemorrhagic tumour $5 \mathrm{~cm}$. in diameter was present in the lower lobe of the left lung, but no obvious origin from bronchi was noted. Haemorrhagic metastases were present in the hilar and mediastinal lymph nodes, in the right adrenal gland, and in the soft tissues of the left forearm anterior to the interosseous septum. No origin from or invasion of the radius or ulna was found. The pulmonary trunk and major branches were patent, but smaller branches in both lungs were occluded by ante-mortem thrombus, which was also present in the right common iliac vein. Histological examination of the lung tumour and other deposits showed highly cellular tumour tissue similar to that seen in the biopsy specimen.

\section{Discussion}

This patient had a relatively small but highly anaplastic giant cell carcinoma of lung with secondaries in hilar nodes, adrenal, and left forearm. The histological features of the tumour were those of giant-cell carcinoma of lung, first described by Nash and Stout (1958) and more recently by Hellstrom and Fisher (1963) and Friedberg (1965). The tumour showed the characteristic features of giant cells and phagocytic activity noted by these and other authors, who regard it as a dedifferentiated adenocarcinoma. Hellstrom and Fisher (1963) found that this type of tumour comprised $3.4 \%$ of their cases of pulmonary carcinoma.

The point of particular interest is the chronic localized haemostatic defect which developed when the tumour was incised. The severity of the blood loss was measured by an isotopic assay and found to be considerable (216 ml./day). Despite blood transfusion it was difficult to maintain the haemoglobin level at $10 \mathrm{~g} . / 100 \mathrm{ml}$. There was no bleeding from other sites and no clinical or laboratory evidence of a systemic haemostatic defect.

As has been described by O'Brien, Thornes, O'Brien, and Hogan (1968), malignant tissue is known to be rich in thromboplastic activity. Significant thromboplastic activity was found in this tumour fluid, and this should in normal circumstances have augmented the tumour's haemostatic mechanism. There were, however, in the tumour fluid, in the washed buffy coat cells of the tumour fluid, and in the tumour itself large amounts of plasminogen activator. Though no plasminogen or plasmin could be detected in the wound fluid it seems that very active fibrinolysis was present in the vicinity of this activatorproducing tumour whereby any plasminogen reaching the area immediately became converted to plasmin and digestion of fibrinogen or fibrin followed, leading to defective haemostasis. Fibrin split products are likely to have been formed and to have contributed to the defective haemostatic mechanism.

Considerable support to this concept was provided by the dramatic response to therapy with aminocaproic acid, which specifically inhibits plasminogen activation and plasmin 
activity ; blood loss fell sharply when aminocaproic acid was given.

It has been suggested that the defibrination syndrome which occurs in malignant disease is due primarily to intravascular coagulation caused by the release of thromboplastic material into the circulation; fibrinolysis may follow as a secondary phenomenon, but primary fibrinolysis is seldom the cause (McKay, 1965;.

The present case illustrates that a malignant tumour may produce large quantities of plasminogen activator. No systemic upset in fibrinolysis occurred, suggesting that systemic inhibitors of plasminogen activation were present in sufficient concentrations to neutralize plasminogen activator reaching the systemic circulation, and it is known that patients with malignant disease have raised levels of antiplasmin in their circulation (Thornes, O'Donnell, and O'Brien, 1967). Had the activator production of the tumour increased with tumour growth it seems possible that the systemic inhibitors of plasminogen might have been overcome and that a primary generalized fibrinolytic state could then have developed.

Surveys of normal human tissues have shown that fibrinolytic activity may be directly related to vascularity, particularly to the content of veins and venules in the tumour (Todd, 1964). The tumour in the present case was found to have no abnormal vascularity and the washed wound fluid buffy coat contained significant plasminogen activator activity, suggesting that this was an inherent property of the cells in the buffy coat. Many of these cells were shown histologically to be tumour cells.

While the evidence for the production of plasminogen activator by the tumour cells is convincing, the demonstration of this activity in cells derived from the tumour which were maintained in monolayer culture must be interpreted with caution because of the nature of the technique.

Bernik and Kwaan (1967) combined microscopical cinematographic and fibrin slide techniques to detect plasminogen activator activity in cells growing out from the edges of adult human kidney explants. The cells were thought to be of endothelial origin. Significant activity was detected in the supernatant growth medium when calf serum, an inhibitor of plasminogen activation (Müllertz, 1957), was omitted.

Evidence has been produced in recent years that tumours may require a fibrin network as a matrix for their growth (Laki and Yancey, 1968). Malignant tumours have been shown to produce a clot-promoting enzyme (O'Meara and Thornes, 1961) which may be thrombin (Laki and Yancey, 1968) and which may ensure adequate fibrin deposition in the vicinity of the tumour. Further studies with isotopically labelled fibrin have shown that fibrin accumulates in the region of tumours (Laki and Yancey, 1968). However, despite producing large amounts of plasminogen activator, which could be expected to result in a defective or absent fibrin matrix, the tumour described in this report was very invasive and rapidly growing.

Systemic coagulation was normal in the present patient; the prolonged euglobulin lysis time and increased resistance to lysis by urokinase in the urokinase sensitivity test suggest increased systemic inhibition of fibrinolysis, which may explain the localization of the haemostatic defect. The pattern of lysis in the fibrin plate experiments suggests the presence of inhibitors of plasmin in the wound fluid.

Tumours of lung have now been reported to have many "paraneoplastic" activities (Greenberg, Divertie, and Woolner, 1964). This particularly rare tumour of lung, a giant-cell carcinoma, illustrates yet another paraneoplastic property, pathological plasminogen activator production.

We are grateful to Mr. A. Murray, Dr. G. A. McDonald, Professor E. M. McGirr, and Professor T. Symington for their interest in this study; to Professor J. N. Davidson, Professor M. Smellie, and Dr. I. McPherson for cell culture facilities; to the Medical Research Council and the Scottish Home and Health Department for financial assistance; to Miss P. O'Neil for technical assistance; and to Mr. T. Parker for photomicrographs.

\section{REFERENCES}

Albrechtsen, O. K. (1957). Brit. 7. Haemat., 3, 284.

Bernik, M. B., and Kwaan, H. C. (1967). F. Lab. clin. Med., 70, 650.

Dacie, J. V., and Lewis, S. M. (1963). Practical Haematology, 3rd ed., p. 297. London.

Denson, K. W. E. (1966). In Treatment of Haemophilia and other Coagulation Disorders, p. 344, erlited by R. Biggs and R. G. Macfarlane. Oxford.

Douglas, A. S. (1962). Anticoagulant Therapy, p. 279. Oxford.

Friedberg, E. C. (1965). Cancer (Philad.), 18, 259.

Greenberg, E., Divertie, M. B., and Woolncr, L. B. (1964). Amer. j. Med., 36, 106.

Hellstrom, H. R., and Fisher, E. R. (1963). Cancer (Philad.), 16, 1080.

Laki, K., and Yancey, S. T. (1968). In Fibrin gen, p. 359, edited by K. Laki. London.

McKay, D. G. (1965). Disseminated Intravascular Cragulation, p. 68. New York.

McNicol, G. P., Barakat, A. A., and Douglas, A. S. (1965). Scot. med. f., 10, 189 .

McNicol, G. P., and Douglas, A. S. (1964). In Recent Adrances in Clinical Pathology, series IV, p. 197 , edited by S. C. Dyke. London.

Merskey, C., Kleiner, G. J., and Johnson, A. J. (1966). Blood, 28, 1.

Moscona, A. (1961). Exp. Ceil Res., 22, 455.

Müllertz, S. (1957). Ann. N.Y. Acad. Sci., 68, 38.

Nash, A. D., and Stoui, A. P. (1958). Cancer (Philad.), 11, 369.

O'Brien, E. T., Tilornes, R. D., O'Brien, D., and Hogan, B. (1968), Lancet, 1, 173 .

O'Meara, R. A. Q., and Thornes, R. D. (1961). Irish 7. med. Sci., No. $423,106$.

Paul, J. (1959). Cell and Tissue Culture. Edinburgh.

Puck, T. T., and Marcus, P. I. (1955). Proc. nat. Acad. Sci., 41, 432.

Ratnoff, O. D., and Menzie, C. (1964). In Blood Coagulation, Haemorrhage, and Thrombosis, 2nd ed., p. 224, edited by L. M. Tocantins and L. A. Kazal. London.

Soulier, I. P., Prou-Wartelle, O., and Josso, F. (1964). Thrombos. Diathes. haemorrh. (Stuttg.), Suppl. No 13, p. 123.

Straub, P. W., Riedler, G., and Frick, F G. (1967). f. clin. Path., 20, 152.

Tagnon, H. J., Schulman, P. Whitmore, W. F., jun., and Leone, L. A. (1953). Amer. F. Med., 15, 875. Thornes, R. D., O'Donneli, Y. M., and O'Brien, D. J. (1967). Irish. F.
med. Sci., No. 494. p 73.

Todd, A. S. (1964). Brit. med. Bull., 20, 210. 